May - 2021

\title{
Impact of Changes in Teaching Methods During the COVID-19 Pandemic: The Effect of Integrative E- Learning on Readiness for Change and Interest in Learning Among Indonesian University Students
}

Anggun Resdasari Prasetyo, Harlina Nurtjahjanti, and Lusi Nur Ardhiani

Faculty of Psychology, Universitas Diponegoro, Indonesia

\begin{abstract}
The COVID-19 pandemic has forced universities to conduct online learning, requiring lecturers to create innovative e-learning methods and students to be ready to adapt and show high interest in learning. This study aimed to examine the effect of an integrative e-learning method on students' readiness and interest in learning at Universitas Diponegoro, Indonesia. This research was experimental, designed with one group pretest and posttest, and no control group. As many as 190 students participated, selected using clustered random sampling. Two measurement scales were used: the readiness for change scale and the interest in learning scale. The statistical analysis technique used was a paired sample $t$-test. The results of paired sample $t$-test analysis on readiness for change $(p=0.000 ; p<0.05)$ and interest in learning ( $p=0.000 ; p<0.05)$ showed significant differences between the pretest and posttest data. The findings indicated that students who participate in integrative e-learning show significant change in the level of readiness and interest in learning.
\end{abstract}

Keywords: integrative e-learning, change readiness, interest in learning, university student 


\section{Introduction}

An organization should be able to adapt to any changes, including challenges and competitions, that occur in its environment. The ability to adapt is essential for an organization to survive and expand. An organization's readiness for change is considered an essential factor in the ability to adapt. One challenge, however, is the unexpected external factor that requires an immediate organizational response. COVID-19 is one of those external factors that has demanded change and adaptation across all fields in Indonesia.

The COVID-19 pandemic began in the first quarter of 2020. The spread of the virus has led to an acute health crisis, causing governments, including Indonesia's, to issue social distancing policies. Such restrictions have affected the implementation of learning in tertiary institutions in Indonesia. The Circular of the Minister of Education and Culture (number 3 of 2020, dated 3 March 2020), concerning the prevention of the spread of COVID-19 in education units, requires all lecture activities to be conducted online. Online learning is defined as a form of learning where physical interaction between teachers and students is absent, and face-to-face meetings occur virtually (Shopova, 2014).

The COVID-19 pandemic conditions resulted in extraordinary changes. In the field of education in Indonesia, all levels immediately adopted online learning (Kotera et al., 2020). This was quite challenging, considering that the COVID-19 situation arose very abruptly, and no one had been prepared for it. Both university educators and students were among those who felt the heavy impact of those changes (Kotera et al., 2020). People reported feeling physical and psychological pressure. As an organizational unit, both lecturers and college students had to adapt to new social, health, and economic conditions (Kotler \& Keller, 2009).

COVID-19 can also be seen as an opportunity to expand the use of technology in education, in line with the notion of the fifth industrial revolution in which there is expected to be a huge shift in the interaction between people and machines (George \& George, 2020). It is predicted that during and after the COVID-19 pandemic, people will grow accustomed to the current e-learning method, and it will become the new learning culture in education (Rada, 2001). This adaptation is viewed positively because readiness for change is one requirement an organization needs to find effective problem-solving methods (Hamel \& Valikangas, 2003). Thus, readiness for change at the individual and organizational level has a vital role to play in responding to uncertainties and evolving environmental changes. Readiness for change describes the beliefs, attitudes, and goals of an organization's members regarding the extent of change needed and how capable the organization might be in successfully implementing those changes (Rafferty et al., 2013). This is a cognitive tendency regarding the behavior observed, whether rejecting or supporting the change effort.

This current study focuses on students at Universitas Diponegoro, where the researchers are employed as teaching staff. The researchers wished to explore the effectiveness of the integrative e-learning method which replaced face-to-face learning due to the pandemic. The second reason for this research is to examine the implementation of work from home (WFH) at Universitas Diponegoro. WFH is a government program aimed at limiting the spread of COVID-19. This WFH program applies to almost all workplaces, including educational institutions. WFH entails that education institutions suspend and replace all offline teaching and learning activities with online teaching and learning activities. Students and lecturers continue to learn and teach, but from their respective houses. At first glance, the e- 
learning program seemed relatively simple to implement, due to the availability of gadgets (e.g., laptop, cellphone, computer) and network data. However, a preliminary study on 30 psychology students at Universitas Diponegoro revealed that students started to face obstacles a week before the implementation of the new learning regime. Among them, not all students had access to a good Internet connection or enough network data. Additionally, these students worried about changes in the learning method because so much depended on the method and technology.

Universitas Diponegoro created an online learning method called integrative e-learning, a form of a learning management method. It is a software that virtualizes the conventional teaching and learning process to aid with administration, documentation, and reporting. It also provides a platform to share content in online classrooms, events, e-learning programs, and training. For example, all features related to the management of the teaching and learning process (e.g., managing classes, teaching materials, discussion forums, scoring, and the online exam) are accessible online. This integrated method is considered an efficient and suitable application of distance learning (Dahiya et al., 2016). In distance learning, lecturers and students do not meet face to face directly, but rather while they are in different places and perhaps at different times, using the e-learning method chosen to achieve educational goals. At Universitas Diponegoro, it involves the use of Microsoft Teams, which has been integrated into the LMS and the website used to access it SIAP UNDIP (must be accessed at https://siap.undip.ac.id). Implementing an integrative e-learning program at Universitas Diponegoro is not merely an attempt to adhere to the WFH policy, but also a step towards adapting to a digital era. The online learning method will, therefore, become a primary learning method at Universitas Diponegoro.

Universitas Diponegoro considered several critical elements when designing its integrative e-learning program. The platform allows students to upgrade their skills, read learning materials, look for information, and conduct group discussions with team members. At the same time, lecturers can be present to review the material. Additionally, it provides a method for students to track their learning progress, access supplementary material, and participate in examinations. There are two main approaches to learning: asynchronous and synchronous. Asynchronous learning refers to interactions that occur sometimes with long delays, where the speed depends on the responses of lecturers and students. Synchronous learning is real-time online learning, meaning that student-lecturer interaction coincides (Van Brakel \& Chisenga, 2003).

Based on the above explanation, students' readiness for change is related to lecture material, psychological skills, and digital skills. Digital skills are needed because face-to-face interaction in class is replaced by virtual face-to-face interaction using digital technology (Keskin et al., 2015). Digital skill is the ability to use and manage technology, information, and communication systems (Keskin et al., 2015). The advancement of information and communication technology in learning is considered an external factor that influences the learning process (Alqahtani \& Mohammad, 2015; Babiker, 2015; Mohammad et al., 2015). Therefore, students should be active, creative, and innovative in order to develop themselves.

As in face-to-face learning in class, positive or negative attitudes and experiences in online learning are influenced by several factors such as the presentation of the materials (e.g., exciting animations), the number of activities, and the opportunity for students to share and collaborate with lecturers and classmates. The learning strategy could also provide opportunities to develop students' critical thinking 
skills and support self-directed learners. Similar to organizations, students should possess readiness for change. Holt et al. (2007) stated that individuals who are ready for change have a positive attitude towards organizational change and a desire to implement organizational change. Conversely, if individuals are not ready to change, then they will not be able to keep up and will feel overwhelmed by the speed of change happening in their organization.

Another aspect that determines learning other than readiness for change is the interest in learning. Without an interest in learning, students have difficulties following each learning process. Students' interest in learning supports student learning outcomes (Nemeth \& Long, 2012). Interest has a positive influence on academic learning, knowledge domains, and specific fields of study (Ainley et al., 2002). Hidi and Renninger believed that interest affects three essential aspects of a person's knowledge: attention, goals, and learning (2011, as cited in Wang \& Adesope, 2016).

In contrast to motivation as a driving factor for knowledge, interest is a driving factor for knowledge and attitude (Hidi, 2006). Furthermore, the notion of interest in learning is the attitude of obedience to learning activities, both regarding planning a study schedule and taking the learning effort seriously (Krapp, 2002). There are two kinds of interests, namely personal (individual) and situational. Personal interest in learning is more durable. In contrast, situational interest in learning is usually shown by seeking new information and having a positive attitude towards the learning environment (Woolfolk, 2010).

Interest is a sense of preferability and connection to knowledge or an activity. Djaali (2013) further stated that interest is accepting a relationship between oneself and something outside of oneself. The stronger or closer the relationship, the greater the interest. Sardiman (2009) suggested that interest focuses on a particular object, response to an object, or desire for something. In the context of learning, Hamalik (2003) stated that students have different levels of learning interests. Some students exhibit high interest in learning, characterized by their creativity, curiosity, perseverance, strong will, always trying to meet their needs, and having high ideals. Students with low interest in learning have the opposite characteristics: less creative, apathetic, always wanting to be served, and resistant to change. Based on the description of interest, it can be concluded that students' interest is their willingness to participate in learning activities consistently to understand a concept in achieving learning objectives based on these indicators: interests, pleasure, desires, and attention.

\section{Aim and Hypotheses}

This study aimed to determine the effect of the integrative e-learning method used at the Universitas Diponegoro on students' readiness for change and interest in learning. This research hypothesis proposed that there would be a difference in university students' readiness for change and interest in learning after implementing the integrative e-learning method.

\section{Methodology}

\section{Research Design}

The research design was experimental; there was only one group pretest and posttest. The intervention (integrative e-learning) was observed, pretest and posttest, for its effectiveness on the experimental 
group without comparison to a control group. This study did not allow for a control group because all classes at the Faculty of Psychology, Universitas Diponegoro were delivered with the integrative elearning method due to government requirements related to the pandemic.

\section{Participants}

A total of 193 students ( 155 female and 38 male) from the Faculty of Psychology, Universitas Diponegoro were selected to participate in this study using cluster random sampling. The sampling method was conducted by randomly selecting groups of students from batch 2017 ( $n=72$ students), batch 2018 ( $n$ $=56$ students), and batch 2019 ( $n=65$ students), but in the implementation of this research there were three students who did not take part in the learning process, so they could not be measured. In the absence of these three students, the research subjects became 190 students (153 female and 37 male), namely in details, batch 2017 ( $\mathrm{n}=71$ students), batch 2018 ( $\mathrm{n}=55$ students), and batch 2019 ( $\mathrm{n}=64$ students).

\section{Procedure}

The intervention in this research was the integrative e-learning program, a learning method at the Universitas Diponegoro that employs information technology in the teaching-learning process. The method is a e-learning method that combines learning principles and technology to reduce face-to-face interaction. The learning processes at Universitas Diponegoro are integrated into SIAP, an application available at Google PlayStore. This application allows students to record their attendance.

Scheduling integrative e-learning is more flexible because it can be adjusted to the agreement between lecturers and students. The lecturer must develop e-learning modules, fill and upload in forms at SIAP UNDIP about lesson plans and prepare lecture material such as PowerPoint/video presentations, discussion forums, and quizzes/assignments, following the guidelines for implementing e-learning lectures.

Discussions in e-learning can be arranged in groups or with individuals all responding to a single question or comment. Group presentations or discussions can be done by streaming. Once students have downloaded the material, they can take part in discussions and complete quizzes/assignments. Students must attend at least 16 online meetings. The SIAP application is also used when students take the mid-term and the final test. The final score for each student is displayed in the SIAP application.

\section{Measurement}

Two measurement tools were used in this study: the readiness for change scale and the interest in learning scale. Both scales were distributed to students before and after they had taken a course using the integrative e-learning method. There were 16 meetings during the course.

The readiness for change scale was based on the dimensions for change constructed by Holt et al. (2007). The scale consisted of 32 items, with a range of five responses for favorable items ( $1=$ strongly disagree to $5=$ strongly agree $)$ and five responses for unfavorable items $(1=$ strongly agree to $5=$ strongly disagree). Aspects of the readiness for change scale included: (a) appropriateness, (b) change efficacy, (c) management support, and (d) personal valence. The blueprint for the readiness for change scale is shown in Table 1. 


\section{Appropriateness}

This aspect looks at whether individuals believe a proposed change is appropriate for an organization. Individuals believe that there are logical reasons for change and understand the needs in planning the proposed change, focusing on the benefits of change for the organization, the efficiency gained from implementing changes, and the congruence between organizational goals and change objectives.

\section{Change Efficacy}

Individuals have beliefs about implementing change, where they acknowledge their skills and ability to carry out their duties/obligations related to change. This dimension measures how confident individuals and groups are that they will be able to implement the changes well. Research conducted by Bandura shows that, in general, individuals avoid activities that are considered beyond their abilities. Therefore, individuals must believe that they can perform the new behavior demanded by change. Otherwise, the results may be less optimal.

\section{Management Support}

This aspect considers individual perceptions regarding whether the organization (i.e., university and faculty management) is committed and supportive of the change implementation. This dimension examines whether students perceive that they received support from campus management in making the change successful. Individuals or recipients of change will consider the integrity of the leaders of the organization. If individuals perceive that support for change is inadequate, acceptance of these changes may be hampered.

\section{Personal Valence}

This aspect looks at personal feelings concerning individual advantages and disadvantages of a proposed change. Personal benefits suppress the positive and negative results of a change, intrinsic and extrinsic benefits, and a sense of justice. This dimension explains the benefits felt by individuals when they implement changes proposed by an organization such as campus management.

\section{Table 1}

Blueprint of Change Readiness Scale

\begin{tabular}{llccc}
\hline \multirow{2}{*}{ Dimension } & \multicolumn{1}{c}{ Indicator } & \multicolumn{2}{c}{ Item } & Total \\
\cline { 2 - 3 } Appropriateness & $\begin{array}{l}\text { Individual knowledge about } \\
\text { the reasons for change }\end{array}$ & 1,3 & 14,30 & 4 \\
& $\begin{array}{l}\text { Understand the purpose of the } \\
\text { change }\end{array}$ & 31,9 & 2,20 & 4 \\
Change efficacy & $\begin{array}{l}\text { Individual ability to carry out } \\
\text { tasks }\end{array}$ & 23,29 & 18,10 & 4 \\
$\quad \begin{array}{l}\text { Individual's confidence in } \\
\text { personal competencies to } \\
\text { carry out the task }\end{array}$ & 15,27 & 32,4 & 4
\end{tabular}




$\begin{array}{lccc}\text { Management support } \quad \begin{array}{l}\text { Individuals observe that the } \\ \text { organization is committed to } \\ \text { change }\end{array} & 5,21 & 26,16 & 4 \\ \quad \begin{array}{l}\text { Individuals feel the support } \\ \text { from the organization to } \\ \text { successfully implement } \\ \text { changes }\end{array} & 19,11 & 6,22 & 4 \\ \text { Personal valence } & \begin{array}{l}\text { Individuals are aware that the } \\ \text { changes provide } \\ \text { improvements in material } \\ \text { circumstances }\end{array} \\ \quad \begin{array}{l}\text { Individuals perceive that the } \\ \text { work environment is better if } \\ \text { changes are made }\end{array} & 17,13 & 24,8 & 4\end{array}$

Total

Note. The number of items on this scale was 32 at the time of the try-out implementation. $\mathrm{F}=$ favorable or positive items; UF = unfavorable or negative items.

The scale was tested on 30 students in the Faculty of Psychology, Universitas Diponegoro. This scale has the value of internal consistency $\alpha=0.919$, and only four items were dropped after tested: items 2 , 15,31 , and 32. One example of an item on the readiness to change scale is: "I am not worried about changes in the teaching and learning process during the work from home period due to the updates I receive from the faculty."

The second scale was the interest in learning scale. The interest in learning scale was based on aspects constructed by Djaali (2003). This scale consisted of 15 items, with a range of five responses for favorable item ( $1=$ strongly disagree to $5=$ strongly agree $)$. The aspects of the learning interest scale used in this study were: (a) feelings of pleasure: individuals interested in a lesson have an interest in the learning; (b) attention in learning: attention is the concentration or direction of one's passion towards observation, understanding, or others, putting aside other things; (c) knowledge: individuals interested in a lesson have extensive knowledge about the lesson and the benefits of learning in everyday life; and (d) awareness: an effort made consciously to learn and realize directed behavior to achieve expected goals in learning interactions. One example of the items on the scale of interest in learning is: "I am happy to study all psychology courses this semester." Table 2 shows the blueprint for the scale of interest in learning. 
Table 2

Blueprint of Scale of Interest in Learning

\begin{tabular}{lcc}
\hline \multicolumn{1}{c}{ Aspect } & Item & Total \\
\hline Interest in learning & $1,2,3,4$ & 4 \\
Focused on the learning process & $5,6,7,8$ & 4 \\
Extensive knowledge & $9,10,11,12$ & 4 \\
High awareness of learning & $13,14,15$ & 3
\end{tabular}

Note. The number of items on this scale was 15 at the time of the try-out implementation.

This learning interest scale was tested on 30 students in the Faculty of Psychology, Universitas Diponegoro. The scale was analyzed using Cronbach's alpha and resulted in an internal consistency $\alpha=$ o.882. Only one item was eliminated, which was item 6 .

The effect of implementing the integrative e-learning method was measured using paired sample $t$-tests to examine differences before and after in the research group. Data were analyzed using the software SPSS 21. In addition to the primary analysis, which measured the impact of implementing integrative e-learning on student academic achievement, a descriptive analysis was conducted to explore students' satisfaction with integrative e-learning.

\section{Results}

The level of readiness for change and interest in learning before and after implementation of the integrative e-learning method can be viewed in Table 3 .

Table 3

Paired Sample t-Tests for Pretest and Posttest Scores in Change Readiness and Interest in Learning

\begin{tabular}{lccccccc}
\hline \multirow{2}{*}{ Aspect } & \multicolumn{2}{c}{ Pretest } & \multicolumn{2}{c}{ Posttest } & \multirow{2}{*}{$t$} & $d f$ & $p$ \\
\cline { 2 - 5 } & $M$ & $S D$ & $M$ & $S D$ & & & \\
\hline $\begin{array}{l}\text { Change } \\
\text { readiness }\end{array}$ & 93.40 & 13.52 & 105.75 & 13.448 & -15.666 & 189 & .ooo* $^{*}$ \\
$\begin{array}{l}\text { Interest in } \\
\text { learning }\end{array}$ & 46.92 & 7.862 & 56.15 & 5.050 & 18.785 & 189 & .0o\% $^{*}$ \\
\hline
\end{tabular}

Note. Statistically significant differences for change readiness and interest in learning between before and after implementing integrative e-learning are in bold. $p=0.000 ; \mathrm{p}<0.05$.

The results of the paired sample $t$-test on the data of change readiness show a significant difference between the pretest and posttest data (mean pretest $=93.40$; mean posttest $=105.75 ; d f=189 p=$ $0.000 ; p<0.05$ ). The results of the paired sample $t$-test on the data on interest in learning also show a significant difference between pretest and posttest data (mean pretest $=46.92$; mean posttest $=52.16$; 
$d f=189 ; p=0.000 ; p<0.05)$. Furthermore, effect size shows that integrative e-learning had a large impact on readiness for change $(d=.76)$ and interest in learning $(d=1.39)$. This suggests the research hypothesis is accepted. The implementation of integrative e-learning at Universitas Diponegoro has had a positive impact or a significant outcome on change readiness and interest in learning. Thus, integrative e-learning is recommended as an ongoing program.

Researchers also analyzed data on learning achievement before and after applying this learning method. This analysis was added because the success or failure of an e-learning program must also be measured by its impact on academic achievement. Achievement is a real ability resulting from the interaction among various internal and external factors in learning (Sardiman, 2009). Achievement is derived from work persistence, where each person pursues his or her respective fields and abilities. The achievement also acts as proof of the effort that a student has made. Based on achievement, self-achievement includes both learning achievement (often called academic achievement) and non-academic achievement. Academic achievement is a learning process that students experience, producing knowledge, understanding, application, analytical power, synthesis, and evaluation. Bloom (1956, as cited in Sardiman, 2009) stated that student academic achievement is a process carried out by students to obtain desired goals (e.g., academic grades). The results of data analysis using the paired sample $t$-test are shown in Table 4.

\section{Table 4}

Paired Samples Statistics for Student Achievement

\begin{tabular}{ccccccccc}
\hline \multirow{2}{*}{ Aspect } & \multicolumn{2}{c}{ Pretest } & \multicolumn{2}{c}{ Posttest } & \multirow{2}{*}{ t } & & \\
& $M$ & $S D$ & $M$ & $S D$ & & & \\
\hline Student achievement & 75.88 & 3.355 & 83.74 & 3.117 & -26.573 & 189 & .ooo $^{*}$ \\
\hline
\end{tabular}

Note. Statistically significant differences for student achievement before and after implementing integrative e-learning are highlighted in bold $(p=.000, p<.05)$.

Student achievement data were taken from quiz scores before and after the implementation of integrative e-learning. The results of a paired sample $t$-test show a significant difference in student achievement pretest and posttest (mean pretest $=75.88$; mean posttest $=83.74 ; d f=189 ; p=0.000 ; p$ $<0.05$ ). This result shows that student achievement significantly increased after implementation of the integrative e-learning method.

The researchers in this research also conducted a descriptive analysis of student satisfaction after the implementation of integrative e-learning method. The concept of satisfaction applies in all working situations, as in companies, governments, schools, and universities. In this case, satisfaction related to the application of integrative e-learning was analyzed. The level of student satisfaction with integrative e-learning is important to assess in order to determine whether the program runs well. Students will feel satisfied if there is a match between their abilities, skills, and expectations and the integrative elearning they received. Satisfaction influences motivation and provides optimum output.

Student satisfaction is measured from two aspects, namely satisfaction towards lecturers' online teaching capability as well as toward the e-learning method. The researchers conducted a descriptive analysis of student satisfaction because, as Bolton and Drew (1991) explained, satisfaction and 
dissatisfaction could indicate disconfirmation between past expectations and current performance. Likewise, Kotler (2003) stated that satisfaction refers to how content a person feels after comparing his or her perception of a performance or service with his or her initial expectation. Table 5 describes student satisfaction with the integrative e-learning application.

\section{Table 5}

Description of Student Satisfaction With the Integrative E-Learning Application

\begin{tabular}{|c|c|c|c|c|c|c|}
\hline Number & Aspect & Description & $\begin{array}{c}\text { Very } \\
\text { satisfied }\end{array}$ & Satisfied & Dissatisfied & $\begin{array}{c}\text { Very } \\
\text { dissatisfied }\end{array}$ \\
\hline \multirow[t]{2}{*}{1} & \multirow[t]{2}{*}{ Reliability } & $\begin{array}{l}\text { The number of meetings } \\
\text { per semester reached } \\
\text { the maximum target } \\
\text { (16 times) }\end{array}$ & 100 & 65 & 25 & o \\
\hline & & $\begin{array}{l}\text { Quality of lecturers in } \\
\text { lecture management }\end{array}$ & 85 & 70 & 15 & 20 \\
\hline & & $\begin{array}{l}\text { The application of e- } \\
\text { learning enhanced the } \\
\text { student experience }\end{array}$ & 70 & 120 & o & o \\
\hline 2 & Satisfaction & $\begin{array}{l}\text { E-learning management } \\
\text { provided student } \\
\text { satisfaction }\end{array}$ & 145 & 45 & o & o \\
\hline
\end{tabular}

Note. The total number of respondents per aspect was 190.

Based on these results, it can be concluded that students were satisfied with the integrative e-learning implementation, and thus, the institution's implementation of this e-learning method has been a success.

\section{Discussion}

This analysis shows that students in the Faculty of Psychology, Universitas Diponegoro, have a high readiness for change and interest in learning when using the integrative e-learning method. Additionally, data suggest an increase in student achievement following implementation of the elearning method. This finding is supported by a previous study that claimed student achievement could be influenced by students' readiness for learning and interest in learning (Abrantes et al., 2007). In this study, the increase in student achievement could be attributed to students who were ready to learn. To provide the correct answers to quizzes and other testing, students must have read and understood the course material. With greater readiness of learning, students are more motivated to optimize their learning outcomes.

This study's results are also in line with a study by Hamalik (2003), who explained that students' readiness for learning, which consists of aspects such as physical, mental, emotional, needs, and 
knowledge, also determines learning achievement outcomes. The more ready a student is, the easier it will be to accept the lecturer's material and achieve good results.

Additionally, a high interest in learning has a positive impact, especially on student achievement. Integrative e-learning has been proven to increase student achievement, evident through the paired sample $t$-test result. Katz et al. (2006) explained that a person interested in a particular subject tends to pay more attention. High interest and attention will have a positive impact on learning achievement. According to Katz et al. (2006), an interesting activity is continuously watched with pleasure to obtain satisfaction. Furthermore, interest plays an essential role in learning. If a subject does not meet students' expectations, students will be reluctant to study, and, as a result, their achievements will not be satisfactory.

Conversely, if the subject attracts interest, it will be more easily learned and understood. Tremendous interest in learning tends to produce high achievement; conversely, less interest in learning results in low achievement. According to Serin (2017), interest can be defined as a tendency, high enthusiasm, or great desire for something. A student who studies material with great interest will get better results than one who has less or no interest in similar material.

Turning to the integrative e-learning model used as the primary teaching method in university or college, this study offers several insights. First, students in this study showed significant positive results, partly because most university students now are part of Generation $Z$ (born between the mid- to late nineties and the early 2010s), who are able to adapt faster and be more in tune with e-learning. Flew (2008) stated that Generation Z's characteristics were formed by the convergent era of social media, in which anyone can control the media to produce various messages. The production and reproduction of messages are delivered cheaply and massively and are driven by participation. Moreover, Generation Z has mastered this technology.

The application of e-learning has many advantages. It can shorten learning time and facilitate interaction between students and lecturers, and among fellow students. Also, students can share information and access teaching materials at any time and continuously. In these ways, e-learning is a more student-oriented learning process. Under such conditions, students can strengthen their mastery of learning materials.

E-learning strategies emphasize students' learning activities. Teaching is no longer understood as a process of transferring information, but as a vehicle to facilitate a better understanding of the process to achieve that knowledge (Arbaugh, 2005; Bolliger \& Wasilik, 2009). Teachers become facilitators and students become researchers and analysts. In addition to receiving class materials, they deepen their understanding by searching for relevant literature and analyzing how it would be translated practically.

One aspect of e-learning that universities must develop in order to implement this method successfully is e-learning readiness. Chapnick (2000, as cited in Aydin \& Tasci, 2005) described eight components of e-learning readiness. First, psychological readiness considers the perspective of e-learning initiatives. This factor is essential to successful implementation. Second, socio-psychological readiness considers the interpersonal aspects of the environment where the program is being implemented. Third, environmental readiness considers the need for greater power in stakeholders, both inside and outside the organization. Fourth, human resources readiness considers and assesses the human resource 
support methods. Fifth, financial readiness considers budget estimates and allocations. Sixth, the readiness to apply technological skills is considered and tested. Seventh, equipment readiness concerns ownership of appropriate equipment. Lastly, content readiness considers the learning content and learning objectives.

Aside from the readiness aspect, the success of an e-learning method can also be determined by how closely the method meets the technology acceptance model (TAM). The TAM has five primary constructs (Davis, 1989): (a) perceived usefulness, (b) perceived ease of use, (c) attitude toward using technology, (d) behavioral intention to use, and (e) actual technology use. The descriptive results of student satisfaction at Universitas Diponegoro (see Table 5) reflect elements of the TAM.

\section{Conclusion and Implications}

This research suggests that implementation of the integrative e-learning method at Universitas Diponegoro was positive. The method can be applied to other universities, although some improvements are still required pending further investigations. The COVID-19 situation has forced conventional learning models to be replaced with e-learning. We predict that this method will continue to be a primary learning method in various education sectors because it complements the current trend to promote education and information technology integration in this era of the fifth industrial revolution.

In an e-learning model, learning resources are easily accessible through the Internet by both lecturers and students. Teaching materials can then be saved in the e-learning method. Lecturers could benefit from the ease that the method offers, particularly during the examination period, when the method could automatically grade some exams. Lecturers need not worry that some students might not have accessed the learning materials because these would have been directly distributed to students through the e-learning method. This efficiency allows lecturers to spend more time with students.

The integrative e-learning model has the potential to streamline the teaching and learning process. Therefore, universities should offer lecturers the necessary facilities (i.e., a good internet network) and infrastructure to support e-learning implementation so as to have a positive effect on education in Indonesia.

\section{Acknowledgments}

This research was supported by the Faculty of Psychology, Universitas Diponegoro. We would like to extend our gratitude to our colleagues from the Faculty of Psychology, Universitas Diponegoro, especially the CEPS officers (Centre of Experimental and Psychometrics Studies) and research subjects who significantly contributed to the research. 


\section{References}

Abrantes, J. L., Seabra, C., \& Lages, L. F. (2007). Pedagogical affect, student interest, and learning performance. Journal of Business Research, 6o(9), 960-964.

https://doi.org/10.1016/j.jbusres.2006.10.026

Ainley, M., Hillman, K., \& Hidi, S. (2002). Gender and interest processes in response to literary texts: Situational and individual interest. Learning and Instruction, 12(4), 411-428. https://doi.org/10.1016/S0959-4752(01)00008-1

Alqahtani, M., \& Mohammad, H. (2015). Mobile applications' impact on student performance and satisfaction. TOJET: The Turkish Online Journal of Educational Technology, 14(4), 102-112. http://www.tojet.net/articles/v14i4/14410.pdf

Arbaugh, J. B. (2005). Is there an optimal design for online MBA courses. Academy of Management Learning and Education, 4(2), 135-149. https://doi.org/10.5465/amle.2005.17268561

Aydin, C. H., \& Tasci, D. (2005). Measuring readiness for e-learning: Reflections from an emerging country. Educational Technology and Society, 8(4), 244-257. J-ets.net/collection/publishedissues $/ 8 \quad 4$

Babiker, M. E. (2015). For effective use of multimedia in education, teachers must develop their own educational multimedia applications. TOJET: The Turkish Online Journal of Educational Technology, 14(4), 62-68. http://www.tojet.net/articles/v14i4/1446.pdf

Bandura, A. (1997). Self efficacy. W.H. Freeman and Company.

Bolliger, D. U., \& Wasilik, O. (2009). Factors influencing faculty satisfaction with online teaching in higher education. Distance Education, 30(1), 103-116. https://doi.org/10.1080/01587910902845949

Bolton, R. N., \& Drew, J. H. (1991). A longitudinal analysis of the impact of service changes on customer attitudes. Journal of Marketing, 55(1), 1-9. https://doi.org/10.2307/1252199

Dahiya, S., Jaggi, S., Chaturvedi, K. K., Bhardwaj, A., Goyal, R. C., \& Varghese, C. (2016). An elearning system for agricultural education. Indian Research Journal of Extension Education, 12(3), 132-135.

Djaali. (2013). Psikologi pendidikan [Educational psychology]. Bumi Aksara.

Davis, F. D. (1989). Perceived usefulness, perceived ease of use, and user acceptance of information technology. MIS Quarterly, 13(5), 319-339. https://doi.org/10.2307/249008

Flew, T. (2008). New media: An introduction. Oxford University Press.

George, A.S., \& George, A.S.H. (2020). Industrial revolution 5.0: the transformation of the modern manufacturing process to enable man and machine to work hand in hand. Journal of Seybold Report, 15(9), 214-234. https://seyboldjournal.com/industrial-revolution-5-0-the- 
transformation-of-the-modern-manufacturing-process-to-enable-man-and-machine-towork-hand-in-hand/

Ghavifekr, S., \& Rosdy, W. A. W. (2015). Teaching and learning with technology: Effectiveness of ICT integration in schools. International Journal of Research in Education and Science (IJRES), 1(2), 175-191. https://ijres.net/index.php/ijres/article/view/79

Hamalik, O. (2003). Manajemen belajar di perguruan tinggi [Learning management at higher education]. Sinar Baru Algensindo.

Hamel, G., \& Välikangas. (2003, September). The quest for resilience. Harvard Business Review, 81(9), 52-63. https://hbr.org/2003/o9/the-quest-for-resilience

Hidi, S. (2006). Interest: A unique motivational variable. Educational Research Review, 1(2), 69-82. https://doi.org/10.1016/j.edurev.2006.09.001

Holt, D. T., Armenakis, A. A., Field, H. S., \& Harris, S. G. (2007). Readiness for organizational change: The systematic development of a scale. Journal of Applied Behavioral Science, 43(2), 99-112. https://doi.org/10.1177/0021886306295295

Katz, I., Assor, A., Kanat-Maymon, Y., \& Bereby-Meyer, Y. (2006). Interest as a motivational resource: Feedback and gender matter, but interest makes the difference. Social Psychology of Education, 9, 27-42. https://doi.org/10.1007/s11218-005-2863-7

Kotera, Y., Green, P., Rhodes, C., Williams, A., Chircop, J., Spink, R., Rawson, R., \& Okere, U. (2020). Dealing with isolation using online morning huddles for university lecturers during physical distancing by COVID-19: Field notes. The International Review of Research in Open and Distributed Learning, 21(4), 238-244. https://doi.org/10.19173/irrodl.v21i4.4843

Kotler, P., \& Keller, K. L. (2009). Manajemen pemasaran [Marketing management]. PT Indeks.

Kotler, P. (2003). Marketing management (11th ed.) Prentice Hall International.

Krapp, A. (2002). Structural and dynamic aspects of interest development: Theoretical considerations from an ontogenetic perspective. Learning and Instruction, 12(4), 383-409. https://doi.org/10.1016/S0959-4752(01)00011-1

Mohammad, H., Fayyoumi, A., \& AlShathry, O. (2015). Do we have to prohibit the use of mobile phones in classrooms? International Journal of Interactive Mobile Technology, 9(2), 54-57. https://doi.org/10.3991/ijim.vgi2.4394

Nemeth, J., \& Long, J. G. (2012). Assessing learning outcomes in U.S. planning studio courses. Journal of Planning Education and Research, 32(4), 476-490. https://doi.org/10.1177\%2F0739456X12453740

Ozdamar-Keskin, N., Ozata, F. Z., Banar, K., \& Royle, K. (2015). Examining digital literacy competences and learning habits of open and distance learners. Contemporary Educational Technology, 6(1), 74-90. http://doi.org/10.30935/cedtech/6140 
Rada, R. (2001). Understanding virtual universities. Intellect.

Rafferty, A. E., Jimmieson, N. L., \& Armenakis, A. A. (2013). Change readiness: A multilevel review. Journal of Management, 39(1), 110-135. https://doi.org/10.1177/0149206312457417

Serin, H. (2017). The role of passion in learning and teaching. International Journal of Social Sciences and Educational Studies, 4(1), 60-64. https://doi.org/10.23918/ijsses.v4i1p60

Shopova, T. (2014). Digital literacy of students and its improvement at the University. Journal of Efficiency and Responsibility in Education and Science, 7(2), 26-32. https://doi.org/10.7160/eriesj.2014.070201

Sardiman. (2009). Interaksi dan motivasi belajar mengajar [Teaching and learning interaction and motivation]. PT Raja Grasindo Persada.

Van Brakel, P., \& Chisenga, J. (2003). Impact of ICT-based distance learning: The African story. The Electronic Library, 21(5), 476-486. https://doi.org/10.1108/02640470310499867

Wang, Z., \& Adesope, O. (2016). Exploring the effects of seductive details with the 4-phase model of interest. Learning and Motivation, 55, 65-77. https://doi.org/10.1016/j.lmot.2016.06.003

Woolfolk, A. (2010). Educational psychology: Active learning edition. Pustaka Pelajar.

Athabasca

University

(9) (1) 